\title{
CULTIVATION POSSIBILITIES OF SOME COMMON BEANS VARIETIES UNDER SECOND CROP CONDITIONS
}

\author{
M. TUNC ${ }^{1}$, B.T. BICER ${ }^{1, *}$, Z. TURK ${ }^{2}$ \\ *E-mail: tbicer@dicle.edu.tr
}

Received: Apr. 18, 2020. Revised: May, 21, 2020. Accepted: June 05, 2020. Published online: July 18, 2020

\begin{abstract}
This research was carried to determine the yield and yield components on some common bean (Phaseolus vulgaris) varieties in 2017 and 2018 years, in Diyarbakir, southeast Anatolia of Turkey. In the experiment, Onceler-98, Karacasehir-90, Yunus-90, Akman-98, Goynuk-98, Aras-98, Terzibaba, Adabeyazi, Cihan and Noyanbey cultivars were used. Experiment was set up in randomized complete block design with three replications. Plots were $6 \mathrm{~m}$ length with five rows, the inter-row and intra-row spacing were $0.7 \mathrm{~m}$ and $0.10 \mathrm{~m}$. Seeds were sown after wheat harvest as second crops. The differences among cultivars were significant for number of days of flowering and maturity, plant height, number of pods and seeds per plant, grain yield and 100 seed weight. Number of days to flowering ranged from 48.0 to 62.8; number of days to maturity ranged from 99.8 to 113.8 . The number of pods and seeds per plant varied from 12.8 to 30.8 , and 24.3 to 105.6 , respectively. Grain yield ranged from $792.3 \mathrm{~kg} \mathrm{ha}{ }^{-1}$ (Cihan and Noyanbey) to $2709 \mathrm{~kg} \mathrm{ha}^{-1}$
\end{abstract}

(Goynuk-98 and Onceler-98). In the experiment area, high heat temperature and high evaporation throughout July and August, negatively affected the blooming, pollination and fertilization on cultivars of dwarf and determinate plant habit types. Brushy type and late-maturing varieties should be preferred under second crop conditions.

Keywords: dry bean; Phaseolus vulgaris; yield.

\section{INTRODUCTION}

The domestication of Phaseolus vulgaris (common bean) occurred independently in South America and Central America, leading to two different domesticated gene center, the Andean and Mesoamerican, respectively (Debouck et al., 1993). The common bean is currently estimated to be one of the most important legumes worldwide. It is an important source of nutrients,

\footnotetext{
${ }^{1}$ Dicle University, Faculty of Agriculture, Department of Field Crops, Diyarbakir, Turkey

${ }^{2}$ Agriculture Vocational High School, Dicle University, Diyarbakir, Turkey
} 
representing $65 \%$ of total protein consumed, $32 \%$ of energy, and a major source of micronutrients (iron, zinc, thiamin and folic acid) (Broughton et al., 2003; Fageria et al., 2010). The annual global dry bean production is approximately 31 million metric tons, and the highest producer is India continent. Turkey total dry bean production exceeds 220000 metric tons, of which $65 \%$ are produced in Center of Turkey. Bean production is almost half that of chickpea.

A large part of bean production in Turkey takes place on both small and big farms, ranging from 1 to 10 ha in size, ranged on sloping land and low fertility to high fertility land (FAO, 2019). Southeastern of Turkey is a very hot and dry summer seasons. Dry bean is not cultivated in the region for many years due to the high temperature and high evaporation. Dry beans are only grown about 1 or 1.5 ha, which has a cool and wet climate, as called micro-climate. In the last 30 years, with irrigation projects in the region, corn and cotton cultivation has become widespread, and this has increased the relative humidity rate of the region. Bean production became possible thanks to increased irrigation possibilities and high humidity. Also, local farmers were very interested in bean cultivation practices and cultivars. In this study, the possibilities of beans, especially after wheat harvest, were investigated in the second crop cultivation.

\section{MATERIAL AND METHODS}

This research was conducted out at Dicle University Agriculture Faculty, Diyarbakir, southeast Anatolia of Turkey during 2017 and 2018 growing seasons. The Diyarbakir is located on grid $37.91^{\circ} \mathrm{N}, 40.2^{\circ} \mathrm{E}$, at an altitude of $640 \mathrm{~m}$ above sea level. The area receives rainfall with an annual mean below about $500 \mathrm{~mm}$, with a wide variation between the years. Precipitation is mainly received from November to May, and between June and October is not. Mean temperature is about $30-35^{\circ} \mathrm{C}$ in June to September. The relative humidity varies between $20 \%$ and $35 \%$ in June to September, and evaporation is very high (Table 1). Prior to planting, soil samples were taken from the field for soil fertility analyses. The soil analysis indicate that soils are neutral ( $\mathrm{pH}: 7.5$ ), unsufficient in organic matter $(0.63 \%)$ and phosphorus content $\left(20.0 \mathrm{~kg} \mathrm{ha}^{-1}\right)$ with clay texture.

Ten dry bean varieties, namely, Onceler-98, Aras-98, Terzibaba, Karacasehir-90, Adabeyazi, Yunus-90, Akman-98, Noyanbey, Cihan and Goynuk-98, were sourced from different Agricultural Research Institute of Turkey. Yunus-90, Goynuk-98, Onceler-98, Terzibaba, Aras-98, Noyanbey, Cihan are a dwarf shrubs habit, and Noyanbey and Cihan are dwarf and determinate type I. Karacasehir-90, Adabeyazi and Akman98 are semi-climbing growth habit.

Experiment was laid out in a randomized complete block design, with three replications, over two years. Plots were $6 \mathrm{~m}$ length with five rows, the interrow and intra-row spacing were $0.7 \mathrm{~m}$ and $0.10 \mathrm{~m}$. Sowing dates were June 16, 2017 and June 20, 2018. 
Table 1 - Meteorological data in Diyarbakir, Southeastern Turkey

\begin{tabular}{lccccccccc}
\hline \multirow{2}{*}{ Months } & \multicolumn{3}{c}{$\begin{array}{c}\text { Mean temperature } \\
\left({ }^{\circ} \mathbf{C}\right)\end{array}$} & \multicolumn{2}{c}{} & \multicolumn{3}{c}{ Total precipitation } & \multicolumn{3}{c}{$\begin{array}{c}\text { Moisture } \\
(\mathbf{m m})\end{array}$} \\
\cline { 2 - 11 } & $\mathbf{2 0 1 7}$ & $\mathbf{2 0 1 8}$ & $\begin{array}{c}\text { Long- } \\
\text { term }\end{array}$ & $\mathbf{2 0 1 7}$ & $\mathbf{2 0 1 8}$ & $\begin{array}{c}\text { Long- } \\
\text { term }\end{array}$ & $\mathbf{2 0 1 7}$ & $\mathbf{2 0 1 8}$ & $\begin{array}{c}\text { Long- } \\
\text { term }\end{array}$ \\
\hline June & 26.7 & 26.5 & 26.2 & 2.6 & 14.4 & 8.0 & 30.6 & 37.9 & 35.0 \\
\hline July & 32.3 & 31.2 & 31.1 & 0.0 & 0.0 & 0.7 & 19.8 & 24.2 & 26.0 \\
\hline August & 31.1 & 31.5 & 30.4 & 0.0 & 0.8 & 0.4 & 23.0 & 24.1 & 26.0 \\
\hline September & 26.9 & 31.2 & 24.9 & 0.0 & 4.15 & 3.9 & 22.0 & 20.0 & 30.0 \\
\hline October & 17.3 & 18.8 & 17.3 & 1.0 & 35 & 32.2 & 35.8 & 52.4 & 48.0 \\
\hline November & 10.1 & 10.2 & 9.5 & 21.2 & 59 & 54.2 & 67.4 & 80.2 & 66 \\
\hline
\end{tabular}

The plots were irrigated with drip irrigation, total $600 \mathrm{~mm}$ of water was applied, and applications were twice a week. $\mathrm{N}$ and $\mathrm{P}$ fertilizers were applied to the plots, as recommended doses: $200 \mathrm{~kg} \mathrm{~N} \mathrm{ha}^{-1}$ (as starter in the form of urea) and $100 \mathrm{~kg} \mathrm{ha}^{-1} \mathrm{P}_{2} \mathrm{O}_{5}$ (as triple superphosphate). Trifluralin was applied pre-emergence at $800 \mathrm{~g}$ a.i./ ha to control weeds. Subsequent weed control was by hoeing.

Plants were harvested at end of October and at the beginning of November, in both years. At maturity stage, yield components, viz. plant height, days to flowering, days to maturity, number of pod per plant, number of seeds per plant and 100-seed weight were determined on a randomly selected subsample of 10 plants. Matured pods were harvested, hand threshed, and weighed. Seed yield was adjusted to 16 - 18\% seed moisture content.

To minimize the border effect, all samplings in each plot were done only on four central rows of $4 \mathrm{~m}$ (leaving two border rows and $0.5 \mathrm{~m}$, at the beginning and at the end of each row).

Data were subjected to analysis of variance (ANOVA) using MSTAT-C (Freed et al., 1991). Means were compared at the $5 \%$ level of significance, using Fisher's protected least significant difference (LSD).

\section{RESULTS AND DISCUSSION}

Analysis of variance for seed yield and its components on common bean varieties was given Table 2 . Variety, year and year $\times$ variety interaction were significant $(p<0.01)$ for days to flowering and days to maturity (Table 2).

Number of days to flowering ranged from 48.0 to 62.8, variety Yunus-90 and Goynuk-98 (61.0 days) late flowered. Variety Adabeyazi was early flowered. Number of days to flowering among years ranged from 58.3 in 2017 to 53.8 in 2018.

Number of days to maturity ranged from 99.8 in Adabeyazi to 113.8 in Goynuk-98. Number of days to maturity among years ranged from 108.1 to 105.7 (Table 3), and flowering and maturity traits were affected by environmental factors.

Variety and year were significant $(p<0.01)$ for plant height (Table 2). Plant height ranged from $55.8 \mathrm{~cm}$ to $162.7 \mathrm{~cm}$. 
Table 2 - Analysis of variance for seed yield and its components on common bean varieties

\begin{tabular}{|c|c|c|c|c|c|c|c|c|}
\hline & \multicolumn{8}{|c|}{ Mean square } \\
\hline & Df. & $\begin{array}{l}\text { Days to } \\
\text { flowering }\end{array}$ & $\begin{array}{l}\text { Days to } \\
\text { maturity }\end{array}$ & $\begin{array}{l}\text { Plant } \\
\text { height }\end{array}$ & $\begin{array}{l}\text { Number of } \\
\text { pods plant }^{-1}\end{array}$ & $\begin{array}{l}\text { Number of } \\
\text { seeds plant }{ }^{-1}\end{array}$ & $\begin{array}{l}\text { Seed } \\
\text { yield }\end{array}$ & $\begin{array}{c}\text { 100-seed } \\
\text { weight }\end{array}$ \\
\hline Year & 1 & $312.817^{\star \star}$ & $88.81^{\star \star}$ & $660.01^{\text {** }}$ & 221.95 & $1330.76^{\star \star}$ & $248107^{\star \star}$ & $52.26^{\star}$ \\
\hline Error & 4 & 2.583 & 3.06 & 29.16 & 36.50 & 3.96 & 2443 & 10.46 \\
\hline Variety & 9 & $122.594^{\star \star}$ & $84.97^{\star \star}$ & $10684.8^{\star \star}$ & $189.72^{\star \star}$ & $4138.27^{\star \star}$ & $292302^{\star \star}$ & $354.45^{\star \star}$ \\
\hline $\begin{array}{l}\text { Year* } \\
\text { Variety }\end{array}$ & 9 & $5.409^{* *}$ & $22.26^{\star *}$ & 120.2 & $34.19 *$ & 92.57 & $13130 \star \star$ & $7.63^{*}$ \\
\hline Error & 36 & 2.546 & 4.62 & 60.13 & 16.46 & 75.45 & 3749 & 3.18 \\
\hline CV \% & & 2.85 & 2.01 & 7.83 & 16.7 & 17.19 & 173.8 & 4.69 \\
\hline
\end{tabular}

Semi-climbing

Adabeyazi (162.7 cm) and Karacasehir-90 (153.0 cm), had the maximum plant height. Although Terzibaba $(146.7 \mathrm{~cm})$ was a dwarf variety, it was among the tallest ones. Yunus-90 (55.8 cm) and Onceler-98 $(59.5 \mathrm{~cm})$, among dwarf varieties, had the shortest plant height (Table 3).

Other studies report that plant height ranged from about $35 \mathrm{~cm}$ to $60 \mathrm{~cm}$ in same varieties, but in different ecologies (Ozbekmez, 2015; Yeken et al., 2018; Bildirici and Demir, 2019). In our study, irrigation water was applied total $600 \mathrm{~mm}$, to prevent the flower abortion, due to high evaporation. The amount of water was increased the plant height and stem diameter more than it should be. Especially, in dwarf types, the plant height was reached an abnormal size. El-Noemani et al. (2009) reported that increasing the irrigation level up to $100 \%$ increases vegetative growth (plant height, number of branches, leaf area, root and stem dry matter), due to the positive effect of water on cell division. In order to prevent overgrowth of the plant stem, irrigation water should be stopped towards the end of the pod setting period.

Variety and variety $\times$ year interaction for number of pods per plant were significant $(p<0.01$ and $p<0.05$, respectively) (Table 2 ), and number of pods per plant ranged from 12.7 in Noyanbey to 30.8 in Karacasehir-90. Variety $\times$ year interaction revealed that in first experiment year, the number of pods of all varieties, except for Yunus-90, Cihan and Akman-98varieties, ishigher than second year ones (Table 3).

The number of pods is higher in semi-climbing types, than dwarf and determinate type I ones. In the experiment area, the weather was hot, $40^{\circ} \mathrm{C} / 30^{\circ} \mathrm{C}$ day/night, and continued throughout July and August. In dwarf and determinate types of varieties, such as Cihan and Noyanbey, since flowers are formed at the upper point of the plant, high temperature negatively affected flowering, pollination and fertilization. Although some flowers was pollinated and fertilized, the pods have resulted in a zygotic-embryo. High air temperature 
with high evaporation and the problem of pollination caused by temperature in dwarf and determinate growth types is an important productivity problem, such as our experiment area. The reason why our irrigation water amount is high is to increase productivity in dwarf types at least, but no success has been recorded on it.

Young et al. (2004) reported in Brassica napus that high temperature stress during flowering, decreases seed production in many plants. Also, under heat stress, flowers either developed into seedless, parthenocarpic fruit or aborted on the stem. During the heat stress, pollen viability and germinability were slightly reduced. Gupta et al. (2015), on pearl millet, revealed that the day-time maximum temperature beyond $42^{\circ} \mathrm{C}$ and the associated increase in VPD during flowering time linearly reduced seed set. Varieties with semi-climbing plant type covered the soil and prevented evaporation. The pods formed under branches and leaves were able to escape the negative effects of the hot. But still, some semi climbing varieties had low number of pods per plant, due to their genetic potential of genotypes, as reported by El-Noemani et al. (2010).

Table 3 - Days to flowering, days to maturity, plant height and number of pods per plant in common bean varieties

\begin{tabular}{lcccccccccccc}
\hline & $\begin{array}{c}\text { Days to flowering } \\
\text { (days) }\end{array}$ & $\begin{array}{c}\text { Days to maturity } \\
\text { (days) }\end{array}$ & \multicolumn{2}{c}{$\begin{array}{c}\text { Plant height } \\
\text { (cm) }\end{array}$} & \multicolumn{3}{c}{$\begin{array}{c}\text { Number of pods } \\
\text { plant }^{-1}\end{array}$} \\
\hline Varieties & $\mathbf{2 0 1 7}$ & $\mathbf{2 0 1 8}$ & Mean & $\mathbf{2 0 1 7}$ & $\mathbf{2 0 1 8}$ & Mean & $\mathbf{2 0 1 7}$ & $\mathbf{2 0 1 8}$ & Mean & $\mathbf{2 0 1 7}$ & $\mathbf{2 0 1 8}$ & Mean \\
\hline Terzibaba & 55.3 & 49.7 & 52.5 & 99.33 & 109.0 & 104.2 & 154.0 & 139.3 & 146.7 & 30.0 & 23.2 & 26.6 \\
\hline Yunus-90 & 64.3 & 61.3 & 62.8 & 108.7 & 110.7 & 109.7 & 56.3 & 55.3 & 55.8 & 19.4 & 21.0 & 20.2 \\
\hline Cihan & 55.3 & 53.3 & 54.3 & 106.7 & 109.7 & 108.2 & 73.3 & 76.0 & 74.6 & 18.0 & 18.5 & 18.3 \\
\hline Noyanbey & 59.0 & 56.7 & 57.8 & 107.7 & 103.3 & 105.5 & 66.3 & 72.6 & 69.5 & 15.6 & 9.68 & 12.7 \\
\hline Aras-98 & 56.3 & 50.3 & 53.3 & 104.0 & 106.0 & 105.0 & 74.0 & 74.0 & 74.0 & 27.3 & 25.3 & 26.3 \\
\hline $\begin{array}{l}\text { Karacasehir- } \\
\text { 90 }\end{array}$ & 56.6 & 50.3 & 53.5 & 107.7 & 105.0 & 106.3 & 162.7 & 143.3 & 153.0 & 37.3 & 24.2 & 30.8 \\
\hline Goynuk-98 & 64.3 & 57.7 & 61.0 & 112.3 & 115.3 & 113.8 & 81.3 & 62.3 & 71.8 & 30.4 & 24.0 & 27.2 \\
\hline Onceler-98 & 61.0 & 58.6 & 59.8 & 108.0 & 111.0 & 109.5 & 61.7 & 57.3 & 59.5 & 30.5 & 28.0 & 29.3 \\
\hline Akman-98 & 60.3 & 54.3 & 57.3 & 104.7 & 109.7 & 107.2 & 126.3 & 118.0 & 122.2 & 25.3 & 27.8 & 26.5 \\
\hline Adabeyazi & 50.6 & 45.3 & 48.0 & 98.0 & 101.7 & 99.8 & 167.0 & 158.3 & 162.7 & 24.6 & 18.3 & 21.5 \\
\hline Mean & 58.3 & 53.8 & & 108.1 & 105.7 & & 102.3 & 95.7 & & 25.8 & 21.9 & \\
\hline LSD (0.05) & 2.61 & & 2.55 & 3.12 & & 2.77 & 12.84 & & 8.65 & 6.71 & & 9.68 \\
\hline
\end{tabular}

Means followed by the same letter within a column are not significant different according to LSD (0.05).

Kumar et al. (2016) reported that pulses are particularly sensitive to heat at flowering and pod development stages. If the crop encounters a few days of exposure to high temperatures $\left(30-35^{\circ} \mathrm{C}\right)$ at these stages, heavy yield losses are reported, due to flower drop and pod abortion. However, this sensitivity varies from genotype to genotype.

Variety and year for number of seeds per plant were significant 


\section{YIELD AND YIELD COMPONENTS ON COMMON BEAN VARIETIES UNDER IRRIGATION CONDITIONS}

$(p<0.01)$ (Table 2), and number of seeds per plant ranged from 12.0 in Noyanbey to 105.6 in Karacasehir-90. Karacasehir-90 variety is a smallseeded variety, and had a lot of seeds per pod (Table 4). Although determinate type varieties (Cihan and Noyanbey) and some semi-climbing varieties had pods per plant, were not produced more than 1 or 2 seeds in the pod. In our study, high irrigation $(600 \mathrm{~mm})$ and heat increased plant height and number of pods per plant, but not number of seeds per plant, due to low seeds per pod. Sehirali (1988) and Sita et al. (2017) reported that the dry bean grows optimally at temperatures of 18 to $24^{\circ} \mathrm{C}$. The maximum temperature during flowering should not exceed $30^{\circ} \mathrm{C}$. High temperatures during the flowering stage lead to abscission of flowers and a low pod set, resulting in yield loss. Day temperatures upper $35^{\circ} \mathrm{C}$ cause empty mature pods. Cultivated under rainfed conditions, the crop requires a minimum of 400 to $500 \mathrm{~mm}$ of rain during the growing season, but an annual total of 600 to $650 \mathrm{~mm}$ is considered ideal.

Table 4 - Number of seeds per plant, 100-seed weight and seed yield in common bean varieties

\begin{tabular}{lccccccccc}
\hline & \multicolumn{3}{c}{ Number of seeds plant $^{-1}$} & \multicolumn{3}{c}{ 100-seed weight (g) } & \multicolumn{3}{c}{ Seed yield (kg ha $^{-1}$ ) } \\
\hline Varieties & $\mathbf{2 0 1 7}$ & $\mathbf{2 0 1 8}$ & Mean & $\mathbf{2 0 1 7}$ & $\mathbf{2 0 1 8}$ & Mean & $\mathbf{2 0 1 7}$ & $\mathbf{2 0 1 8}$ & Mean \\
\hline Terzibaba & 58.5 & 42.9 & 50.7 & 42.0 & 41.3 & 41.7 & 2111 & 1400 & 1755 \\
\hline Yunus-90 & 35.3 & 34.9 & 35.1 & 44.3 & 41.7 & 43.0 & 1081 & 973.3 & 1027 \\
\hline Cihan & 26.9 & 21.7 & 24.3 & 38.0 & 33.6 & 35.8 & 827.3 & 757.3 & 792.3 \\
\hline Noyanbey & 11.4 & 12.6 & 12.0 & 40.7 & 42.3 & 41.5 & 813.3 & 773.0 & 793.2 \\
\hline Aras-98 & 70.8 & 63.7 & 67.3 & 39.6 & 40.7 & 40.2 & 2439 & 2218 & 2329 \\
\hline K.sehir-90 & 118.3 & 92.9 & 105.6 & 19.0 & 18.0 & 18.5 & 1983 & 1503 & 1743 \\
\hline Goynuk-98 & 60.5 & 47.5 & 54.0 & 49.0 & 44.7 & 46.8 & 3130 & 2289 & 2709 \\
\hline Onceler-98 & 74.0 & 60.7 & 67.4 & 41.3 & 40.0 & 40.7 & 3000 & 2257 & 2629 \\
\hline Akman-98 & 54.7 & 49.2 & 52.0 & 39.0 & 34.0 & 36.5 & 1852 & 1515 & 1684 \\
\hline Adabeyazi & 42.0 & 32.0 & 37.0 & 37.0 & 35.0 & 36.0 & 1887 & 1371 & 1629 \\
\hline Mean & 55.2 & 45.8 & & 39.0 & 37.1 & & 1912 & 1505 & \\
\hline LSD (0.05) & & & 3.19 & 2.95 & & 5.09 & 32.02 & & 25.05 \\
\hline
\end{tabular}

Means followed by the same letter within a column are not significant different according to LSD (0.05).

Variety, year and variety $\times$ year interaction for 100 -seed weight were significant $(p<0.01$ and $p<0.05$, respectively) (Table 2 ), and 100 -seed weight ranged from $18.5 \mathrm{~g}$ in Karacasehir-90 to $46.8 \mathrm{~g}$ in Goynuk-98 (Table 4). Variety $\times$ year interaction revealed that Noyanbey and Aras-98 varieties in first experiment year, but other varieties in the second year had high 100-seed weight. Although 100-seed weight had high heritability, could be affected by soil and climate conditions (Elkoca and Cinar, 2015). Siddique et al. (1999) reported that a few days of exposure to high temperatures $\left(30-35^{\circ} \mathrm{C}\right)$, during seed filling, accelerates senescence, 
diminish seed set and seed weight, and reduce yield in pulses.

Variety, year and year $\times$ variety interaction were significant $(p<0.01)$ for seed yield (Table 2), and seed yield ranged from $792.3 \mathrm{~kg} \mathrm{ha}^{-1}$ to $2709 \mathrm{~kg} \mathrm{ha}^{-1}$. The highest seed yield was in Goynuk-98 (2709 kg ha $\left.{ }^{-1}\right)$ and Onceler-98 (2629 kg ha-1) varieties.

The lowest seed yield was in Cihan (792.3 kg ha ${ }^{-1}$ ), Noyanbey (793.2 kg ha-1) and Yunus-90 (1027 kg ha $\left.{ }^{-1}\right)$ varieties. Seed yield among years ranged from $1912 \mathrm{~kg} \mathrm{ha}^{-1}$ in 2017 to $1505 \mathrm{~kg} \mathrm{ha}^{-1}$ in 2018 (Table 4). Since seed yield is highly affected by environmental conditions, such as climate and soil factors, differences among years for seed yield are generally significant. We observed significantly higher unfilled pods for some genotypes, indicating the impacts of high temperature on pod formation. Kumar et al. (2016) reported that in legumes high temperature during anthesis reduces seed set due to impaired pollen tube growth and fertilization. Especially, in dwarf types, number of pods and seeds per plant were low.

\section{CONCLUSIONS}

It is aimed to determine the suitable semi-climbing and dwarf common bean varieties that can be grown under second crop conditions in this study. Yunus-90 and Goynuk-98 varieties were late flowered and matured. High heat and full irrigation were increased plant height, and plant height was between $55.8 \mathrm{~cm}$ and
$162.7 \mathrm{~cm}$. Cihan and Noyanbey varieties had low number of pods and seeds per plant, due to dwarf and determinate growth habit. Number of seeds per plant and seed yield were negatively affected by heat. Seed yield ranged from $792.3 \mathrm{~kg} \mathrm{ha}^{-1}$ to $2629 \mathrm{~kg} \mathrm{ha}^{-1}$, and the highest seed yield was in Goynuk-98 and Onceler-98 varieties. Also, Aras-98, Akman-98 and Adabeyazi varieties had good performance for this region and such as high heat environments.

\section{REFERENCES}

Bildirici, N. \& Demir, S. (2019). Determination of yield and yield characteristics of some dry beans (Phaseolus vulgaris L.) varieties in the Hakkâri ecological conditions. BEU Journal of Science, 8(4): 12501257.

Broughton, W.J., Hernández, G., Blair, M., Beebe, S., Gepts, P. \& Vanderleyden, J. (2003). Beans (Phaseolus spp.) - model food legumes. Plant Soil, 252(1): 55-128, DOI: 10.1023/A:1024146710611

Debouck, D.G., Toro, O., Paredes, O.M., Johnson, W.C. \& Gepts, P. (1993). Genetic diversity and ecological distribution of Phaseolus vulgaris (Fabaceae) in north-western South America. Econ.Bot., 47: 408-423, DOI: $10.1007 / B F 02907356$.

Elkoca, E. \& Cinar, T. (2015). The adaptation, agronomical and quality characteristics of some dry bean (Phaseolus vulgaris L.) cultivars and lines under Erzurum ecological conditions. Anadolu J.Agric.Sci., 30(2): 141-153, DOI: 10.7161/ anajas.2015.30.2.141-153

El-Noemani, A.A., Aboamera, M.A.H., Aboellil, A.A.A. \& Dewedar, O.M. (2009). Growth, yield, quality and 


\section{YIELD AND YIELD COMPONENTS ON COMMON BEAN VARIETIES UNDER IRRIGATION CONDITIONS}

water use efficiency of pea (Pisum sativum L.) plants as affected by evapotranspiration (ETo) and sprinkler height. Minufiya J.Agric. Res., 34(4): 1445-1466.

El-Noemani, A.A., El-Zeiny, H.A., ElGindy, A.M., El-Sahhar, E.A. \& ElShawadfy, M.A. (2010). Performance of some bean (Phaseolus vulgaris L.) varieties under different irrigation systems and regimes. Aust.J.Basic Appl.Sci., 4(12): 6185-6196.

Fageria, N.K., Melo, L.C., Oliveira, J.P. \& Coelho, A.M. (2012). Yield and yield components of dry bean genotypes as influenced by phosphorus fertilization. Commun. Soil Sci Plant Anal., 43(21): 27522766, DOI: 10.1080/00103624.2012. 719973

FAO (2019). https://biruni.tuik.gov.tr/ medas $/$ ?kn=92\&locale $=$ tr

Freed, R., Eisensmith, S.P., Goetz, S., Reicosky, D., Smail, V.W. \& Wolberg, P. (1991). User's guide to MSTAT-C. Michigan State University, East Lansing, Michigan.

Gupta, S.K., Rai, K.N., Singh, P., Ameta, V.L., Gupta, S.K., Jayalekha, A.K. et al. (2015). Seed set variability under high temperatures during flowering period in pearl millet (Pennisetum glaucum L. (R.) Br.). Field Crops Res., 171: 41-53, DOI: 10.1016/j.fcr.2014.11.005

Kumar, J., Kant, R., Kumar, S., Basu, P.S., Sarker, A. \& Singh, N.P. (2016). Heat tolerance in lentil under field conditions. Legume Genomics Genet., 7: 1-11.

Ozbekmez, Y. (2015). Determination of yield and components with seed and technological characteristics of some dry beans varieties and genotypes on in ecological conditions of Ordu. University of Ordu, Institute for Graduate Studies in Science and Technology, Department of Field Crops, MSc. Thesis.

Siddique, K.H.M., Loss, S.P., Regan, K.L. \& Jettner, R.L. (1999). Adaptation and seed yield of cool season grain legumes in Mediterranean environments of south-western Australia. Aust.J. Agric.Res., 50(3): 375-388, DOI: 10.1071/A98096

Sita, K., Sehgal, A., Hanumantha Rao, B., Nair, R.M., Prasad, P.V.V., Kumar, S. et al. (2017). Food legumes and rising temperatures: effects, adaptive functional mechanisms specific to reproductive growth stage and strategies to improve heat tolerance. Front. Plant Sci. 8: 1658, DOI: 10.3389/fpls. 2017.01658

Sehirali, S. (1988). Grain legume crops. Ankara University, Faculty of Agricultural Engineering, Ankara, Turkey, 1089 (314), 435.

Yeken, M.Z., Kantar, F., Çancı, H., Özer, G. \& Çiftçi, V. (2018). Breeding of dry bean cultivars using Phaseolus vulgaris landraces in Turkey. IntJ.Agr.Wildl.Sci., 4(1): 45-54, DOI: 10.24180/ijaws.408794

Young, L.W., Wilen, R.W. \& BonhamSmith, P.C. (2004). High temperature stress of Brassica napus during flowering reduces micro - and megagametophyte fertility, induces fruit abortion, and disrupts seed production. J.Exp.Bot., 55: 485-495, DOI: $10.1093 /$ jxb/erh038 